\title{
MAJELIS TAKLIM DAN PERANANNYA DALAM PENINGKATAN DAKWAH DI KECAMATAN WARA SELATAN KOTA PALOPO
}

\author{
Ramlah M. \\ Institut Agama Islam Negeri (IAIN) Palopo \\ email : opusana2@gmail.com
}

\begin{abstract}
Religious life in the city of Palopo in recent times again looks lively. It is an indication of a change in social life, the culture of economic politics in society. One form of the development of religious life, especially in the formation of the ummah is the growing splendor majelis taklim institution which is one of the nonformal educational institutions that have the function and role in the guidance of the ummah, as a place of spiritual education and as a place of syiar Islam and silaturrahmi between ulama, umara (government) with the people. This research will examine the important role played by majelis taklim institution in increasing the activity of da'wah and religious development in South Wara Subdistrict of Palopo City.
\end{abstract}

Keywords: Dakwah, Majelis Taklim

\begin{abstract}
Abstrak
Kehidupan keagamaan di masyarakat Kota Palopo pada akhir-akhir ini kembali terlihat semarak. Hal tersebut merupakan indikasi terjadinya perubahan dalam kehidupan sosial, budaya politik ekonomi dalam masyarakat. Salah satu bentuk perkembangan kehidupan keagamaan khususnya dalam pembinaan umat adalah mulai tumbuh semaraknya lembaga majelis taklim yang merupakan salah satu lembaga pendidikan nonformal yang mempunyai fungsi dan peranan dalam pembinaan umat, sebagai tempat pendidikan rohaniah dan sebagai tempat syiar Islam dan silaturrahmi antara ulama, umara (pemerintah) dengan umat. Penelitian ini akan mengkaji peran penting yang dimainkan lembaga majelis taklim dalam meningkatkan aktivitas dakwah dan pembinaan keagamaan di Kecamatan Wara Selatan Kota Palopo.
\end{abstract}

Kata Kunci: Dakwah, Majelis Taklim.

\section{PENDAHULUAN}

Seiring kemajuan ilmu pengetahuan dan teknologi, kehidupan manusia selalu menghadapi keniscayaan perubahan, baik dari segi ekonomi, moralitas, serta gaya hidup. Kemajuan ilmu pengetahuan dan teknologi bagaikan dua sisi mata uang yang membawa perubahan positif dan negatif. Oleh karena itu, yang perlu dipersiapkan adalah bagaimana mempersiapkan umat Islam dalam menyikapi perubahan tersebut untuk kemaslahatan kaum Muslimin. ${ }^{1}$

Untuk menyikapi hal tersebut, perlu adanya pembinaan pengetahuan di bidang agama yang dapat meredam hal negatif khususnya pada dekadensi moral. Sebagai contoh, pendidikan agama dan kegiatan keagamaan secara umum adalah hal penting dalam memenuhi kebutuhan jiwa manusia dan membentuk kepribadian yang baik dan mulia, terutama pendidikan dan kegiatan-kegiatan keagamaan yang bernuansa Islam.

${ }^{1}$ Didin Hafidhuddin, Dakwah Aktual, (Cet. I; Jakarta: Gema Insani, 1998), h. 88-96. 
Posisi strategis majelis taklim yang berdiri sejajar dengan lembaga pendidikan lainnya seperti sekolah, madrasah atau pesantren menempatkan dirinya mengakar di masyarakat sehingga peranannya sebagai sarana pembinaan umat sangatlah penting. Kajian tentang Majelis Taklim dan peranannya dalam peningkatan dakwah pernah dilakukan oleh Khoirul Huda, dalam penelitiannya berjudul Peranan dakwah dalam pembentukan kepribadian muslim: studi kasus pada Majelis Taklim Tarbiyatul Mu'awanah. Penelitian tersebut menjelaskan bahwa tingkat stress dan problem sosial masyarakat perkotaan semakin meningkat dan tambah kompleks. Gejala ini ditengarahi karena semakin merebaknya budaya hedonis konsumeristik pada kehidupan masyarakat, terutama kehidupan di kota-kota besar seperti Jakarta. Konsekuensinya adalah telah terjadi perubahan perilaku dan kepribadian masyarakatan perkotaan yang mengalami disorientasi sosialnya, sehingga ia tak hanya mengalami alienasi dan keterasingan diri, tetapi juga berakibat pada tindakan-tindakan individu yang menyimpang dari norma hukum dan agama bahkan destruktif, baik terhadap diri sendiri, keluarga maupun orang lain.

Riset lain oleh Nur Syam, berjudul Islam Pesisir, secara konseptual menolak teoretisasi Weber tentang "Disenchanment of the World" bahwa tidak otomatis merubah tindakan religius akan tetapi dapat dipadukan "rasionalisasi rasionalisasi". Selain itu, temuan ini merevisi teori Clifford Geertz², Beatty ${ }^{3}$, dan Mulder ${ }^{4}$ tentang Islam sinkretik. Lebih jauh, hasil riset ini juga merevisi kajian Mark berkah Woodward dan Muhaimin tentang Islam akulturatif dengan menawarkan label Islam kolaboratif yakni Islam lokal di Jawa merupakan hasil kolaborasi berbagai penggolongan sosial bahwa tradisi di antara mereka. ${ }^{5}$ Dalam penelitian Nur Syam, ajaran Islam dengan tradisi lokal nampak dalam hubungan in harmony (damai) dalam memberikan warna terhadap tradisi. Sementara itu, kajian dalam penelitian disertasi ini akan melihat bagaimana elemen dan varian dakwah (agama dan non-agama) memberikan kontribusi bagi pemberdayaan masyarakat pesisir di Kota Palopo Sulawesi Selatan.

\footnotetext{
${ }^{2}$ Karya Geertz yang paling terkenal dan monumental adalah The Religion of Jawa yang melahirkan tipologi orang Jawa: Santri, Priyayi dan Abangan. Lihat, Clifford Geertz, The Religion of Java, (The United States of America: The University of Chicago Press, 1976), h. 5-7.

${ }^{3}$ Andrew Beatty, Adam and Eve and Vshnu: Syncretism in the Javanese Slametan" dalam Journal of the Royal Anthropological Institute 2,1996. Lihat pula, Andrew Beatty, The Varieties of Javanese Religion, (Princeton University Press, 1999).

${ }^{4}$ Niels Mulder, Agama, Hidup Sehari-hari dan Perubahan Budaya, (Jakarta: Gramedia Pustaka Utama, 1999).

${ }^{5}$ Nur Syam, Islam Pesisir, (Cet. I; Yogyakarta: LKiS, 2005), h. vii. , (Jakarta: Gramedia Pustaka Utama, 1999).
} 


\section{METODE PENELITIAN}

Penelitian ini adalah penelitian lapangan (field study) dengan menggunakan analisa deskriptif yaitu suatu penelitian yang berusaha menggambarkan objek penelitian apa adanya yang berkaitan dengan peranan majelis taklim dalam pengembangan dakwah. Penelitian ini mengambil lokasi di Kecamatan Wara Kota Palopo.

Teknik Pengolahan dan Analisis Data menggunakan metode deduksi. Secara operasional analisis data kualitatif dilakukan dengan tiga langkah sistematis secara jalin menjalin yakni reduksi data, penyajian data, dan penarikan simpulan.

\section{GAMBARAN UMUM MAJELIS TAKLIM DI KECAMATAN WARA SELATAN}

Majelis Taklim ini bermula dari berkumpulnya beberapa ibu-ibu rumah tangga yang kemudian sepakat mengundang ustadz atau penceramah untuk datang mengisi pengajaian. Setalah berjalan beberapa waktu, hal tersebut kemudian disampaikan kepada pemerintah setempat yang akhirnya direspon dengan baik. ${ }^{6}$ Majelis Taklim di Kecamatan Wara Selatan mengalami perkembangan yang cukup signifikan dan tersebut tergolog cukup aktif dalam mengembangkan beberapa kegiatan antara lain: pengajian bulanan, arisan keluarga, pengajian Takziyah, membaca Yasinan dan Tahlil. ${ }^{7}$

Pada umumnya Majelis Taklim di Kecamatan Wara Selatan dalam pelaksanaan kegiatannya banyak bekerja sama dengan pengurus Mesjid dan anggota PKK. Kegiatan pada Majelis Taklim banyak menyentuh aspek kehidupan ibadah dan muamalah. Bahkan pada sebahagian pelaksanaan pengajian bulanan yang diadakan di Wara Selatan mengagendakan beberapa pertemuan untuk membahas cara dan praktik ibadah shalat dan wudhu. Kebijakan ini diambil atas saran dan masukan dari para angota yang merasa belum mempunuyai pengetahuan memadai tentang tata cara Nobenar disadari oleh para anggota Majelis Taklim sehingga berani mengambil suatu trobosan baru.

Sebagai bagian dari organisasi yang berada di tingkat desa, maka Majelis Taklim ini aktif berkordinasi dengan aparat pemerintahan desa. Pada acara-acara berskala besar, misalnya pada pengajian bulanan, tidak jarang melibatkan unusur pemerintahan desa khususnya pada bantuan dana (financial) dan pelibatan masyarakat luas. Beberapa bantuan yang didapatkan Majelis Taklim di Tingkat Kecamatan Wara Selatan.

${ }^{6}$ Fitri, Penyuluh Agama Kecamatan Wara Selatan Kota Palopo, wawancara, tanggal 1 Nopember 2016.

${ }^{7}$ Warkona, Pengurus Majelis Taklim Nurul Yaqin Sampoddo, wawancara, tanggal 1 Nopember 2016. 
Keanggotaan Majelis Taklim tidak didasarkan pada aturan-aturan yang ketat dan mengikat. Keanggotaan pada organisasi Islam ini lebih banyak berdasar pada aspek kekeluargaan dan kesadaran pribadi. Meskipun keaggotaan berdasarkan pada aspek kekeluargaan dan tidak mengikat, namun tidak banyak keluarga Muslim di desa Tiromanda yang mendaftar secara resmi sebagai anggota Majelis Taklim. Namun demikian, ketika mereka dilibatkan pada acara-acara pengajian pada umumnya mereka tidak menolak.

Tabel 1.

Majelis Taklim Kecamatan Wara Selatan Kota Palopo

\begin{tabular}{|c|c|c|c|c|}
\hline $\begin{array}{l}\mathbf{N} \\
\mathbf{0}\end{array}$ & $\begin{array}{l}\text { Nama Majelis } \\
\text { Taklim }\end{array}$ & Pengurus (Ketua) & Alamat & Program \\
\hline $\begin{array}{l}2 . \\
3 . \\
4 . \\
5 . \\
6 . \\
7 . \\
8 .\end{array}$ & $\begin{array}{l}\text { Nurul Yaqin } \\
\text { Sampoddo } \\
\text { Al-Huda Songka } \\
\text { Bani Graha Jannah } \\
\text { Nurus Sa'adah } \\
\text { Al-Ikhlas } \\
\text { Nurul Jannah } \\
\text { Islamic Center } \\
\text { Citra Buana } \\
\text { Nurul Taqwa }\end{array}$ & $\begin{array}{l}\text { Warkona } \\
\text { Wallung } \\
\text { St. Aisyah, S.E. } \\
\text { Habibah, } \\
\text { S.Pd.,M.M.Pd. } \\
\text { Samsiani } \\
\text { Hadisah, S.Ag. } \\
\text { Hj. Hasriani Baso } \\
\text { Hj. Marlasari, S.E. }\end{array}$ & $\begin{array}{l}\text { Kel. } \\
\text { Sampoddo } \\
\text { Kel. Songka } \\
\text { Kel. Songka } \\
\text { Kel. Songka } \\
\text { Kel. Songka } \\
\text { Kel. Takkalalla } \\
\text { Kel. Takkalalla } \\
\text { Kel. Takkalalla }\end{array}$ & $\begin{array}{l}\text { Pengajian } \\
\text { Bulanan } \\
\text { dan Zikir } \\
\text { sda } \\
\text { sda } \\
\text { sda } \\
\text { sda } \\
\text { sda } \\
\text { Pengajian } \\
\text { Bulanan, } \\
\text { Bimbingan } \\
\text { Yasinan } \\
\text { dan } \\
\text { Tahlilan } \\
\text { sda } \\
\text { sda }\end{array}$ \\
\hline
\end{tabular}

Sumber Data: Data Penyuluh Agama Tahun 2016. ${ }^{8}$

Pada dasarnya kaum Muslimin di daerah ini belum memahami manfaat dan pentingnya terlibat dalam acara pengajian dan aktivitas Majelis Taklim. Karena sesungguhnya aktifitas Majelis Taklim pada tahap selanjutnya tidak hanya berkaitan dengan aspek ibadah dan dakwah Islamiyah, tetapi juga nanti akan berhubungan dengan pengembangan sumber daya manusia seperti pelatihan praktis tentang sumber daya manusia. ${ }^{9}$

Menurut pengakuan Samsiani, pada awal berdirinya Majelis Taklim khususnya di Songka, pengajian dan aktifitas dakwah Islamiyah dipusatkan di

8Fitri, Penyuluh Agama Kecamatan Wara Selatan Kota Palopo, wawancara, tanggal 1 Nopember 2016.

${ }^{9}$ Habibah, Pengurus Majelis Taklim Nurus Saadah Kecamatan Wara Utara, wawancara, tanggal 3 November 2016. 
Mesjid di Al-Ikhlsa Songka. ${ }^{10}$ Para anggota cukup pesimis dengan keberadaan organisasi ini. Namun demikian, dengan sikap saling membantu para anggota yang waktu itu masih sangat terbatas, eksistensi Majelis Taklim di al-Ikhlas Songka akhirnya mengalami peningkatan. Bertambahnya anggota merupakan suatu peningkatan yang signifikan dalam organisasi. Tidak gampang memberikan keyakinan bagi masyarakat Muslim mengenai manfaat positif bergambung sebagain anggota pada Majelis Taklim. Meskipun anggotanya tidak begitu banyak, namun dengan jumlah yang ada cukup memberikan motivasi bagi para anggota untuk terlibat aktif. ${ }^{11}$ Oleh karena itu, hal yang akan dilakukan adalah bagaiamana menambah anggota baru dan membina kegiatan-kegiatan keagamaan para anggota Majelis Taklim Nurul Saadah Songka.

\section{BENTUK PEMBINAAN KEAGAMAAN MAJELIS TAKLIM DALAM PENINGKATAN DAKWAH DI KECAMATAN WARA SELATAN}

Aktifitas pembinaan dakwah Majelis Taklim di Kecamatan Wara Selaatan cukup bervariasi berupa pengajian bulanan, pengajian yasinan, zikir dan shalawat, pengajian al-Qur'an untuk ibu-ibu, pengajian takziyah, dan Buka Puasa di Buan Suci Ramadan di masjid-masjid di Kecamatan Wara Sealatan.

\section{Pengajian Bulanan}

Pengajian bulanan ini dilakukan pada umumnya minggu awal setiap bulan di mesjid-mesjid yang tersebar di Kecamatan Wara Selatan: Masjid alIkhlas (Songka), Masjid al-Huda (Songka), Masjid Bani Graha (Songka) Mesjid Citra Graha (Songka), Masjid Nur al-Saadah (Songka), Masjid Pantai Satu (Takkalalla), Masjid Islamic Center (Takkalalla), Masjid Binturu dan Masjid Nur Yasin Babul Khair (Binturu).

Pada umumnya masjid tersebut telah mempunyai pengurus majelis taklim tersendiri yang namanya diambil dari nama masjid yang ada di daerah tersebut. Pengajian bulanan ini dikoordinir oleh pengurus Majelis Taklim bekerjasama dengan pengurus Mesjid. Pada dasarnya pengajian ini terbuka untuk kaum ibu dan bapak. Namun demikian, partisipasi ibu-ibu jauh lebih banyak dan hampir belum pernah ditemukan kaum bapak menghadiri pengajian Majelis Taklim selain ustads atau dai yang berceramah. Pengajian bulanan cukup diminati oleh para anggota. Dalam pengajian tersebut, terdapat penyuluhan agama yang berbasis lisan ini pada dasarnya adalah ceramah agama yang dilakukan oleh para dai atau ustads.

${ }^{10}$ Samsiani, Pengurus Majelis Taklim Ikhlas Songka Kecamatan Wara Utara, wawancara, tanggal 3 November 2016.

${ }^{11}$ Habibah, Pengurus Majelis Taklim Nurul Saadah Songka Kecamatan Wara Selatan, wawancara, tanggal 3 November 2016. 
Tabel 2 menunjukkan bahwa dari 60 responden, terdapat 49 atau 81,66 \% yang menyatakan bahwa mereka tertarik mengikuti pengajain bulanan yang diadakan Majelis Taklim. Sementara itu, terdapat 11 responden atau 18,33 \% di antaranya yang menyatakan antusiasme mereka sedangsedang saja. Kemudian, tidak satupun responden yang menyatakan pengajian bulanan tidak menarik perhatian mereka.

Tabel 2.

Respon Anggota Majelis Taklim Pada Pengajian Bulanan

\begin{tabular}{|l|l|r|l|}
\hline \multirow{2}{*}{ No } & Kategori Jawaban & \multicolumn{2}{|c|}{ Responden } \\
\cline { 3 - 4 } & Menarik & 49 & $81,66 \%$ \\
& Sedang & 11 & $18,33 \%$ \\
& Tidak menarik & - & - \\
\hline \multicolumn{2}{|c|}{ Jumlah } & 60 & $100 \%$ \\
\hline
\end{tabular}

Sumber Data: Hasil olah data pada angket 2016

Ketertarikan para anggota majelis taklim dalam mengikuti pengajian Bulanan Majelis taklim dilatarbelakangi oleh alasan yang bermacam-macam antara lain karena; ingin bertemu (bersosialisasi) dengan para anggota lainnya, merasa malu kalau tidak hadir, ingin ikut arisan bulanan, ingin mendengarkan ceramah agama dan sebagainya. Berdasarkan alasan-alasan para anggota Majelis Taklim tersebut, alasan bersosialisasi merupakan alasan yang paling dominan mengapa mereka ingin mengikuti pengajian majelis taklim diikuti dengan alasan karena ingin mendengarkan ceramah agama. Hal tersebut dapat dilihat pada deskripsi tabel berikut ini:

Tabel 3.

Alasan Mengikuti Kegiatan Majelis Taklim Bulanan

\begin{tabular}{|l|l|r|l|}
\hline \multirow{2}{*}{ No } & \multicolumn{2}{|c|}{ Kategori Jawaban } & \multicolumn{2}{|c|}{ Responden } \\
\cline { 3 - 4 } & & Frekuensi & Persentase \\
\hline 1 & Ingin Bersosialisasi & 23 & $38,30 \%$ \\
2 & Ingin Mendengarkan Ceramah Agama & 20 & $33,30 \%$ \\
3 & Ingin Ikut Arisan Bulanan & 10 & $16,70 \%$ \\
4 & Merasa Malu Kalau Tidak Ikut & 7 & $11,70 \%$ \\
\hline \multicolumn{2}{|r|}{ Jumlah } & 60 & $100 \%$ \\
\hline
\end{tabular}

Sumber Data: Hasil olah data pada angket 2016

Tabel 3 menunjukkan alasan-alasan anggota majelis taklim mengikuti pengajian bulanan. Dari 60 responden yang diteliti, terdapat $23(38,30 \%)$ yang menyatakan bahwa mereka tertarik mengikuti pengajian bulanan karena ingin bersosialisasi, 20 responden $(33,30 \%)$ yang menyatakan karena ingin mendengar ceramah, 10 responden (16.70\%) karena ingin ikut arisan dan 7 responden $(11.70 \%)$ karena merasa malu kalau tidak ikut.

Salah satu alasan kami untuk ikut pengajian bulanan yakni karena kami tertarik ingin mendengar ceramahnya. Kami selalu tertarik untuk ikut karena 
penceramahnya bagus, kadang-kadang dikasih cerita dan kisah lucu-lucu, pokoknya kami tertarik kalau penceramahnya atau ustadznya bagus-bagus. ${ }^{12}$

\section{Yasinan dan Shalawat}

Salah satu kegiatan Majelis Taklim di Kecamatan Wara Selatan yang banyak menyentuh dan berkaitan dengan pembinaan keagamaan yakni pelaksanaan tradisi Yasinan dan pembacaan Shalawat. Kegiatan pembacaan Yasinan dan Shalawat biasanya dirangkaian dengan Pengajian Bulanan. Kedua kegiatan ini baru berkembang lima tahun belakangan karena pengaruh dari tradisi Yasinan yang bekembang dikalangan komunitas masyarakat Jawa Muslim. Namun demikian, seperti dijelaskan H. Zainuddin Samide dan H. Ruslin, cikal bakal tradisi ini sebenarnya sudah dimulai dan telah sering dilaksanakan khususnya pengikut Jam'iyah Nahdlatul Ulama (NU), salah satu organisasi Islam terbesar di Kota Palopo selain Muhammadiyah dan Syarikat Islam. ${ }^{13}$

Menurut pengamatan dan observasi peneliti, tradisi pembacaan Yasinan dan Shalawat ini mempunyai banyak manfaat meskipun sebahagian kalangan menganggapnya bid'ah atau tidak sesuai dengan ajaran Islam. Terlepas dari kontroversi tersebut, beberapa hal dapat menjelaskan nilai positif dari pelaksanaan tradisi tersebut. Pertama, memotivasi para anggota Majelis Taklim untuk mempelajari bacaan al-Qur'an. Tidak jarang juga, pengaruh tradisi tersebut juga diterapkan pada anak-anak para anggota pengajian. Kedua, memperkuat syiar Islam dan menambah nilai estetika (keindahan) dalam beragama. Dengan lantunan shalawat, muncul adanya kesadaran dan kerinduan kepada Nabi Muhammad saw., melalui pembacaan shalawat.

\section{Amaliyah Ramadhan (Buka Puasa dan Ceramah Ramadhan)}

Berbeda dari khutbah jum'at, ceramah ramadhan ini dilaksanakan hanya pada saat bulan suci ramadhan pada tiap tahun. Ceramah Ramadan pada umumnya dilaksanakan sebelum shalat tarawih atau setelah shalat isya. Ceramah ramadhan ini biasanya melibatkan banyak dai yang berbeda-beda pada setiap malam. Jadwal ceramah ramadhan biasanya sudah dijadwal satu bulan sebelum datangnya bulan ramadhan. ${ }^{14}$ Peran majelis taklim di Kecamatan Wara Selatan dalam konteks ini yakni mengatur persiapan Buka Puasa Ramadhan bekerjasama dengan Remaja Masjid dalam menyusun daftar

${ }^{12}$ St. Aisyah, Ketua Majelis Taklim Bani Graha Jannah dan Ruhanda, Penyuluh Agama Islam dan Guru Agama Islam, wawancara, pada tanggal 2 Nopember 2016.

${ }^{13}$ H. Zainuddin Samide dan H. Ruslin, Pengurus dan Tokoh NU Kota Palopo, wawancara, tanggal 12 Oktober 2016.

${ }^{14}$ H.M. Arif, Tokoh Agama, wawancara, pada tanggal 3 Nopmeber 2016 di Palopo. 
yang membawakan buka puasa dan remaja mesjid yang akan membacakan rangkaian acara pada malam shalat tarawih. ${ }^{15}$

Tabel 4.

Respon Anggota Majelis Taklim terhadap Ceramah dan Amaliah Ramadhan

\begin{tabular}{|l|l|l|l|}
\hline \multirow{2}{*}{ No } & \multirow{2}{*}{ Kategori Jawaban } & \multicolumn{2}{|c|}{ Responden } \\
\cline { 3 - 4 } & Menarik & Frekuensi & Persentase \\
\hline 1 & Sedang-sedang & - & $100 \%$ \\
3 & Tidak menarik & - & - \\
\hline \multicolumn{2}{|c|}{ Jumlah } & 60 & - \\
\hline
\end{tabular}

Sumber Data: Hasil olah data pada angket 2016.

Tabel 4 menunjukkan bahwa dari 60 responden, semua responden 60 atau 100 \% yang menyatakan bahwa kegiatan acara ceramah ramadhan dan amaliyah ramadhan menarik bagi mereka. Dari hasil penelitian ini, tidak ada responden yang menjawab lain.

\section{Ceramah Takziyah}

Aktivitas anggota Majelis Taklim tidak hanya terlibat dalam pengajian bulanan dan pembacaan Yasinan-Shalwat. Dalam kondisi tertentu, para anggota Majelis Taklim di Kecamatan Wara Selatan juga terlibat aktif dalam pelaksanaan penajian Takziyah, terutama bagi anggota yang salah seorang di antara keluarganya wafat. Para anggota Majelis Taklim diundang untuk membaca yasinan dan membaca Tahlil. Pada malam harinya, umumnya diadakan pengjian Takziyah dan pemilihan siapa yang akan berceramah dikordinasikan pada pengurus Majelis Taklim kerjasama dengan Imam Desa setempat. 16

Tabel 5.

Respon Anggota Majelis Taklim terhadap Acara Takziyah

\begin{tabular}{|l|l|c|l|}
\hline \multirow{2}{*}{ No } & \multirow{2}{*}{ Kategori Jawaban } & \multicolumn{2}{|c|}{ Responden } \\
\cline { 3 - 4 } & & Frekuensi & Persentase \\
\hline 1 & Aktif & 40 & $66,66 \%$ \\
3 & Sedang-sedang & 15 & $25,00 \%$ \\
\hline \multicolumn{2}{|c|}{ Tumlah } & 5 & $8,33 \%$ \\
\hline
\end{tabular}

Sumber Data: Hasil olah data pada angket 2016.

Tabel 5 menunjukkan bahwa dari 60 responden, terdapat 40 atau $66,66 \%$ yang menyatakan bahwa mereka aktif mengikuti acara Takziyah yang

15Warkona, Pengurus Majelis Taklim Nurul Yaqin Sampoddo, wawancara, pada tanggal 3 Nopember 2016 di Palopo.

${ }^{16}$ St. Aisyah, Pengurus Majelis Taklim Bani Graha Jannah Songka Palopo, wawancara, pada tanggal 3 Nopember 2016. 
dialami oleh salah satu anggota atau bukan anggota Majelis Taklim. Selain itu, terdapat 15 responden atau $25 \%$ di antaranya yang menyatakan respon mereka sedang-sedang saja. Kemudian, hanya 5 responden atau 8,33\% yang menyatakan mereka tidak aktif. Ketidakaktifan mereka tidak disebabkan karena disengaja akan tetapi karena suatu halangan yang tidak bisa dihindari. ${ }^{17}$

Ceramah takziyah ini dilaksanakan berkaitan dengan kematian anggota keluarga muslim. Ceramah takziyah dimaksudkan untuk menghibur keluarga yang ditinggalkan dan menguatkan hati para keluarga untuk bersabar atas takdir dan musibah yang menimpa keluarga. Tema-tema ceramah takziyah lebih banyak menyentuh aspek-aspek kematian, alam barzakh, sabar, tawakkal.

Berdasarkan tradisi yang berkembang pada kaum Muslim di Kota Palopo, khususnya di Kecamatan Wara Selatan. Pelaksanaan takziyah biasanya dilaksanakan selama tiga hari berturut-turut yang mana acara ceramah takziyah pada umumnya dimulai pada malam hari. Pada malam ketiga, keluarga orang yang meninggal menyediakan "hidangan makanan" kepada para keluarga yang turut dalam acara takziyah dengan harapan dan niat agar supaya pahala yang diperoleh dengan menyelenggarakan acara tersebut bisa dikirimkan kepada orang yang meninggal. ${ }^{18}$

\section{Ceramah Aqiqah}

Kegiatan pembinaan keagamaan melalui ceramah sering juga dilakukan dalam bentuk ceramah Aqiqah. Hanya saja, model pembinaan dakwah ini belum menjadi tradisi yang sering dilakukan di Kecamatan Wara Selatan. Ceramah aqikah dilaksanakan sehubungan dengan kelahiran anggota baru dalam suatu keluarga muslim. Acara aqikah dimulai dengan memotong rambut bayi atau anggota keluarga baru sambil membacakan doa dan shalat kepada Nabi Muhammad saw. Meskipun belum menjadi tradisi masyarakat Muslim Kota Palopo, naumun acara pengajian atau ceramah dalam rangka pelaksanakan aqikah dilaksanakan. Ada sedikit perbedaan tradisi pelaksanaan aqikah antara masyarakat Muslim Bugis dan Makassar. Kalau pada masyarakat Muslim-Bugis, pelaksanaan aqikah lebih ramai dibanding dengan acara khitanan. Sementara ada masyarakat Muslim-Makassar, acara khitanan jauh lebih ramai dibanding dengan acara aqikah. ${ }^{19}$

${ }^{17}$ Hj. Suarti, Pengurus Majelis Taklim Nurul Taqwa Kecamatan Wara Selatan Palopo, wawancara, pada tanggal 3 Nopember 2013.

18 Fitri, Penyuluh Agama Kantor Kementerian Agama Kota Palopo, wawancara, pada tanggal 5 November 2013.

${ }^{19}$ Ruhanda dan Fitri, Penyuluh Agama Kantro Kementerian Agama Kota Palopo, wawancara, pada tanggal 5 November 2016. 
Tabel 6 menunjukkan bahwa dari 60 responden, terdapat 60 atau 100 $\%$ yang menyatakan bahwa mereka aktif mengikuti acara aqiqah yang dialami oleh salah satu anggota atau bukan anggota Majelis Taklim. Bisa dijelaskan bahwa aktiftas dakwah dalam bentuk pengajian atau ceramah Islamiyah pada acara aqiqah sangat bermanfaat. Peran anggota Majelis Taklim dalam kegiatan ini adalah mengurus penceramah sekaligus mengambil peran aktif dalam meringankan beban keluarga atau anggota yang melaksanakan hajat.

Tabel 6.

Respon Anggota Majelis Taklim terhadap Acara Aqiqah

\begin{tabular}{|l|l|l|l|}
\hline \multirow{2}{*}{ No } & Kategori Jawaban & \multicolumn{2}{|c|}{ Responden } \\
\cline { 3 - 4 } & & Frekuensi & Persentase \\
\hline 2 & Aktif & 60 & $100 \%$ \\
3 & Sedang-sedang & - & - \\
\hline \multicolumn{2}{|l}{ Tidak Aktif } & - & - \\
\hline
\end{tabular}

Sumber Data: Hasil olah data pada angket 2016.

Berikut ini tanggapan anggota Majelis Taklim mengenai tema-tema dakwah yang diceramahkan oleh penyuluh dalam kegiatan dakwah islamiyah baik pada acara cerama ramadhan, syukuran, aqikah, dan pengajian bulanan, takziyah sebagai berikut:

Tabel 7.

Respon Anggota Terhadap Tema Dakwah di Majelis Taklim

\begin{tabular}{|l|l|l|l|}
\hline \multirow{3}{*}{ No } & \multirow{2}{*}{ Kategori Jawaban } & \multicolumn{2}{|c|}{ Responden } \\
\cline { 3 - 4 } & Menarik & Frekuensi & Persentase \\
& Sedang-sedang & 11 & $81,66 \%$ \\
& Tidak menarik & - & $18,33 \%$ \\
& Jumlah & 60 & - \\
\hline \multicolumn{2}{|l}{} & & $100 \%$ \\
\hline
\end{tabular}

Sumber Data: Hasil olah data pada angket 2016.

Tabel 7 menunjukkan bahwa dari 60 responden, terdapat 49 atau $81,66 \%$ yang menyatakan bahwa mereka tertarik dengan tema-tema dakwah pada Majelis Taklim di Desa Tiromanda. Sementara itu, terdapat 11 responden atau 18,33 \% di antaranya yang menyatakan tema-tema dakwah yang disampaikan para ustadz di Majelis Taklim sedang-sedang saja.

\section{TEMA-TEMA DAKWAH DALAM KEGIATAN MAJELIS TAKLIM DI KECAMATAN WARA SELATAN}

\section{Tema Dakwah tentang Surga dan Neraka}

Tema dakwah ini sangat sering dikemukakan para dai dan ustadz yang memberikan ceramah pada Majelis Taklim. Namun demikian kadang-kadang 
saja jika terlalu sering didengarkan oleh para anggota akan cepat bosan dengan tema dakwah yang tidak bervariasi. Namun demikian bagaimana respon anggota Majelis Taklim pada tema ini dapat dilihat pada tabel sebagai berikut:

\section{Tabel 8.}

Respon Anggota Terhadap Tema Dakwah "Surga dan Neraka"

\begin{tabular}{|l|l|l|l|}
\hline \multirow{2}{*}{ No } & \multirow{2}{*}{ Kategori Jawaban } & \multicolumn{2}{|c|}{ Responden } \\
\cline { 3 - 4 } & & Frekuensi & Persentase \\
\hline 1 & Menarik & 45 & $75 \%$ \\
3 & Kadang-kadang & 15 & $25 \%$ \\
\hline \multicolumn{2}{|l|}{ Tidak menarik } & - & - \\
\hline
\end{tabular}

Sumber Data: Hasil olah data pada angket 2016.

Tabel 8 menunjukkan bahwa dari 60 responden, terdapat 45 reseponden atau $75 \%$ yang menyatakan bahwa mereka tertarik dengan tema dakwah "surga dan neraka" pada Majelis Taklim di Desa Tiromanda. Sementara itu, terdapat 15 responden atau $25 \%$ di antaranya yang menyatakan tema-tema dakwah yang disampaikan para ustadz di Majelis Taklim sedang-sedang saja.

\section{Tema Dakwah tentang Pelaksanaan Ibadah}

Tema dakwah ini cukup sering dikemukakan para dai dan ustadz yang memberikan ceramah pada Majelis Taklim. Namun demikian bagaimana respon anggota Majelis Taklim pada tema ini dapat dilihat pada tabel sebagai berikut:

Tabel 9.

Respon Anggota Terhadap Tema Dakwah "Pelaksanaan Ibadah"

\begin{tabular}{|l|l|l|l|}
\hline \multirow{2}{*}{ No } & \multirow{2}{*}{ Kategori Jawaban } & \multicolumn{2}{|c|}{ Responden } \\
\cline { 3 - 4 } & & Frekuensi & Persentase \\
\hline 2 & Menarik & 50 & $83,33 \%$ \\
3 & Kadang-kadang & 10 & $16,67 \%$ \\
\hline \multicolumn{2}{|c|}{ Tidak menarik } & - & - \\
\hline
\end{tabular}

Sumber Data: Hasil olah data pada angket 2016.

Tabel 9 menunjukkan bahwa dari 60 responden, terdapat 50 reseponden atau 83,33 \% yang menyatakan bahwa mereka tertarik dengan tema dakwah "tata cara pelaksanaan ibadah" pada Majelis Taklim di Desa Tiromanda. Sementara itu, terdapat 10 responden atau 16,67\% di antaranya yang menyatakan tema-tema dakwah yang disampaikan para ustadz di Majelis Taklim sedang-sedang saja.

\section{Tema Dakwah tentang "Kisah-kisah Para Nabi dan Sahabat"}

Tema dakwah ini cukup populer dikalangan para anggota Mejelis Taklim. Namun demikian nampaknya tema dakwah ini sangat digemari oleh 
para anggota karena cara ustadz membawakan cukup santai dan materinya berupa kisah dalam bentuk narasi (cerita). Namun bagaimana respon anggota Majelis Taklim pada tema ini dapat dilihat pada tabel sebagai berikut:

Tabel 10.

Respon Anggota Terhadap Tema Dakwah “Kisah para Nabi dan Sahabat"

\begin{tabular}{|c|c|c|c|}
\hline \multirow[b]{2}{*}{ No } & \multirow{2}{*}{ Kategori Jawaban } & \multicolumn{2}{|c|}{ Responden } \\
\hline & & Frekuensi & Persentase \\
\hline 1 & Menarik & 60 & $100 \%$ \\
\hline 2 & Kadang-kadang & - & - \\
\hline 3 & Tidak menarik & - & - \\
\hline & & 60 & $100 \%$ \\
\hline
\end{tabular}

Sumber Data: Hasil olah data pada angket 2016.

Tabel 10 menunjukkan bahwa dari 60 responden, terdapat 60 reseponden atau $100 \%$ yang menyatakan bahwa mereka tertarik dengan tema dakwah "kisah para Nabi-Sahabat" pada Majelis Taklim di Desa Tiromanda. Sementara itu, tidak ada responden yang menjawab kadangkadang. Nampaknya, tema dakwah yang disenangi oleh para anggota adalah tema dakwah yang tidak berat dan penyampaiannya santai.

\section{Tema Dakwah tentang "Tauhid-Akidah"}

Tema dakwah ini sangat penting dikalangan para anggota Mejelis Taklim. Namun demikian nampaknya tema dakwah ini perlu diberikan pemahaman yang jelas kepada anggota karena materinya sangat penting dalam kehidupan masyarakat Muslim di Desa Tiromanda Kecamatan Bua Kabupaten Luwu. Tema dakwah tentang "Tauhid dan Akidah" akan selalu menjadi tema dakwah dalam pengajian Majelis Taklim. Namun bagaimana respon anggota Majelis Taklim pada tema ini dapat dilihat pada tabel sebagai berikut:

Tabel 11.

Respon Anggota Terhadap Tema Dakwah "Tauhid-Akidah"

\begin{tabular}{|l|l|l|l|}
\hline \multirow{2}{*}{ No } & \multirow{2}{*}{ Kategori Jawaban } & \multicolumn{2}{|c|}{ Responden } \\
\cline { 3 - 4 } & & Frekuensi & Persentase \\
\hline 1 & Penting & 60 & $100 \%$ \\
3 & Kurang Penting & - & - \\
\hline \multicolumn{2}{|c|}{60} & - \\
\hline
\end{tabular}

Sumber Data: Hasil olah data pada angket 2016.

Tabel tersebut menunjukkan bahwa dari 60 responden, terdapat 60 reseponden atau 100 \% yang menyatakan bahwa tema dakwah tentang Tauhid-Akidah sangat penting diberikan kepada anggota pada Majelis Taklim di Desa Tiromanda. Sementara itu, tidak ada responden yang menjawab tidak pentingnya tema dakwah "Tauhid dan Akidah". 


\section{Tema Dakwah tentang "Akhlak-Muamalah"}

Tema dakwah ini cukup populer dikalangan para anggota Mejelis Taklim. Namun demikian nampaknya tema dakwah ini perlu diberikan pemahaman yang jelas kepada anggota karena materinya sangat penting dalam kehidupan masyarakat Muslim di Desa Tiromanda Kecamatan Bua Kabupaten Luwu. Tema dakwah tentang "Tauhid dan Akidah" akan selalu menjadi tema dakwah dalam pengajian Majelis Taklim. Namun bagaimana respon anggota Majelis Taklim pada tema ini dapat dilihat pada tabel sebagai berikut:

Tabel 12.

Respon Anggota Terhadap Tema Dakwah “Akhlak dan Muamalah”

\begin{tabular}{|l|l|l|l|}
\hline \multirow{2}{*}{ No } & \multirow{2}{*}{ Kategori Jawaban } & \multicolumn{2}{|c|}{ Responden } \\
\cline { 3 - 4 } & & Frekuensi & Persentase \\
\hline 1 & Penting & 60 & $100 \%$ \\
3 & Kurang Penting & - & - \\
\hline \multicolumn{2}{|l}{ Tidak penting } & - & - \\
\hline
\end{tabular}

Sumber Data: Hasil olah data pada angket 2016

Tabel 12 menunjukkan bahwa dari 60 responden, terdapat 60 reseponden atau $100 \%$ yang menyatakan bahwa tema dakwah tentang Akhlak-Muamalah sangat penting diberikan kepada anggota pada Majelis Taklim di Desa Tiromanda. Sementara itu, tidak ada responden yang menjawab tidak pentingnya tema dakwah "Akhlak dan Muamalah".

\section{FAKTOR PENGHAMBAT DALAM PENINGKATAN DAKWAH DI KECAMATAN WARA SELATAN}

Hambatan yang dihadapi muballig, ustadz atau para da'i dalam mengembangkan tema-tema dakwah pada Majelis Taklim di Kecamatan Wara Selatan yakni hambatan eksteran dan internal antara lain sebagai berikut:

\section{Hambatan Eksternal (dari luar)}

Hambatan eksternal yang dialami para dai dalam mengembangkan tema-tema dakwah yang lebih efektif dan efesien yakni karena tingkat partisipasi para anggota belum maksimal secara keseluruhan. Pentingnya partisipasi aktif para anggota dalam setiap kegiatan belum terlihat di kalangan para anggota. Selain itu, program-program yang dibuat pengurus Majelis Taklim tidak mengalami perkembangan dari tahun ke tahun. Namun demikian, yang perlu dihargai adalah semangat dan motivasi mereka yang cukup tinggi dan keihlasan mereka dalam mengikuti pengajian Majelis 
Taklim cukup baik. ${ }^{20}$ Sejatinya, pengajian majelis taklim ini mengikutkan dan melibatkan anak-anak remaja para anggota majelis taklim. Hal ini disebabkan karena pentingnya kegiatan pembinaan dakwah ini yang dilakukan bersama dengan orang tua mereka masing-masing. Kegiatan pembinaan keagamaan ini akan mempunyai manfaat lebih banyak jika melibatkan anak-anak para anggota minimal mereka yang sudah berumur balig dalm hal usia.

\section{Hambatan Internal (dari dalam)}

Pertama, kurangnya pemahaman para da'i terhadap berbagai persoalan yang real yang dihadapi oleh para anggota Majelis Taklim yang rata-rata dari kaum Ibu (wanita). Sejauh ini, para da'i belum memahami secara komprehensif mengenai apa yang menjadi masalah real (nyata) dan dialami masyrakat misalnya rendahnya tingkat kesejahtraan, akidah dan tauhid yang masih perlu ditingkatkan, semangat bekerja, dan kehidupan muamalah yang masih perlu ditingkatkan. ${ }^{21} \mathrm{Kedua}$, lemahnya kemampuan metodologis para dai. Pelaksanaan ceramah dan dakwah Islamiyah masih cenderung menggunakan cara-cara konvensional, yaitu ceramah yang bersifat satu arah. Para anggota Majelis Taklim belum mampu terlibat secara partisipatoris sehingga forum pembelajaran itu statis dan monoton. ${ }^{22}$

Pada sisi lain, para dai dan penyuluh agama masih menghadapi persoalan sikap mental dan pengetahuan serta keterampilan, seperti: 1) budaya kerja lemah, dan kurang inisiatif, 2) orientasi pada pencapaian hasil dalam pelaksanaan tugas masih kurang, 3) kurang orientasi pada kepuasan jama'ah sasaran/binaan (customer), akibat kepekaan dan empati terhadap keutuhan stakehorders yang msih rendah, 4) minat untuk menambah pendidikan formal meningkat, tetapi belum diikuti kesadaran pemanfaatan pengetahuan baru dalam menjalankan tugas, lebih banyak tenaga yang kurang memiliki keahlian (unskilled), 5) gagap teknologi, tetapi semangat untuk pengadaan teknologi baru tinggi, dan 6) pemanfaatan informasi baru dalam pelaksanaan tugas masih rendah. ${ }^{23}$

${ }^{20}$ Hadisah, Pengurus Majelis Taklim Nurul Jannah Takkalalla, wawancara, pada tanggal 3 Nopember 2016 di Takkalalla.

${ }^{21}$ H. M. Arif, Tokoh Agama, wawancara, pada tanggal 3 Nopember 2016 di Palopo.

${ }^{22}$ Ruhanda dan Fitri, Penyuluh Agama Kantro Kementerian Agama Kota Palopo, wawancara, pada tanggal 5 November 2016.

${ }^{23}$ Ruhanda dan Fitri, Penyuluh Agama Kantro Kementerian Agama Kota Palopo, wawancara, pada tanggal 5 November 2016. 


\section{SOLUSI DALAM PENINGKATAN DAKWAH DI KECAMATAN WARA SELATAN}

Untuk membantu pemahaman dan kemampuan metodologis ini, sebenarnya dari Depag pusat telah menerbitkan beberapa buku pedoman bagi para penyuluh. Tetapi, buku-buku pedoman itu lebih banyak berisi petunjuk teknis-administratif bagi para penyuluh dalam melaksanakan penyuluhan, seperti; petunjuk teknis jabatan fungsional, pedoman materi bimbingan dan penyuluhan, pedoman identifikasi potensi wilayah dan sebagainya. Lebih dari itu, di samping sosialisasi berbagai juklak dan juknis itu belum efektif, para penyuluh sendiri sebagian besar belum membaca pedoman-pedoman itu.

Selain itu, kesempatan pendidikan dan pelatihan bagi para ustadz dan penyuluh agama yang dilakukan oleh pusat sangat terbatas. Akibatnya, proses pelaksanaan penyuluhan, pendekatan dan kemampuan metodis para penyuluh masih jauh dari memadai sebagai bentuk proses pendidikan (non-formal) yang dapat memberdayakan kesadaran dan pengamalan keislaman khususnya dan kehidupan secara lebih luas pada umumnya. ${ }^{24}$

Sementara itu, di kalangan anak-anak ataupun remaja, cenderung berkembang anggapan bahwa kalau sudah bisa membaca Alquran, mereka merasa belajar agama sudah selesai. Demikian juga di kalangan masyarakat, pengajian rutin mingguan, bulanan atau selapanan, seperti; yasinan, mudzakarah, atau istighasah dapat sebenarnya berjalan. Tetapi, programprogram itu lebih bersifat simbolik sebagai agenda ritual yang bersifat pribadi atau massal. Beberapa kegiatan itu belum mampu menggerakkan kesadaran untuk meningkatkan pemahaman, pengamalan dan penghayatan keagamaan yang lebih baik. ${ }^{25}$

Beberapa problem di atas, adalah masalah besar yang harus diatasi. Tantangan nyata yang perlu dicermati dan dikritisi secara kreatif dan antisipatif, adalah bagaimana mencari langkah antisipatif dan strategis yang dapat dilakukan mulai dari sekarang (jangka pendek) adalah memaksimalkan pengelolaan sumber daya penyuluh secara reguler dan berkelanjutan. Menunggu adanya pembenahan kebijakan dari pusat adalah pekerjaan yang menghabiskan energi (tetapi mutlak diperlukan), sementara kemungkinan hasilnya terlalu sulit untuk diprediksikan.

Untuk itu, beberapa langkah praktis dalam upaya pemberdayaan penyuluh untuk keluar dari keterkungkungan problem internal kelembagaan penyuluh antara lain sebagai berikut :

${ }^{24}$ H, M. Arif, Tokoh Agama, wawancara, pada tanggal 3 Nopember 2016.

${ }^{25} \mathrm{Hj}$. Marlasari dan Hj. Wardah, Pengurus Majelis Taklim Citra Buana dan Majelis Taklim Nurul Rahma, wawancara, pada tanggal 5 Nopember 2013. 
1. Memaksimalkan potensi kreatif pada ustadz dan penyuluh agama secara mandiri dengan memberikan tambahan pengetahuan melalui penataran, seminar-seminar, workshop, pendidikan tambahan, pelatihan dan sebagainya.

2. Menghilangkan budaya menunggu dari atasan, tetapi kreatif menerobos peluang-peluang untuk mampu berkarya secara produktif. Para penyuluh hendaknya kreatif dalam menciptakan program-program serta kegiatan yang dapat mengembangkan aplikasi dan pengamalan ajaran agama Islam bagi masyrakat muslim di Desa Tiromanda Kabupaten Luwu.

Sebahagian di antara penyuluh memang kadang-kadang tidak melaskanakan tugas pokoknya sebagai penyuluh agama dengan baik. Mungkin karena ikatan mereka dengan institusi Kementrian Agama belum resmi sehingga sikap disiplin dalam menjalankan tugasnya belum maksimal seperti yang diharapkan. ${ }^{26}$

3. Mengefektifkan pengorganisian penyuluh di ditingkat kabupaten dan kota sebagai media yang paling strategis untuk melakukan proses pemberdayaan penyuluh, misalnya melalui kajian pustaka, kajian metodologis atau teknologis penyuluhan dan sebagainya.

4. Membuka peluang kerja sama melalui kelompok kerja di tingkat Kandepag/Kanwil dengan lembaga-lembaga sosial keagamaan yang memiliki konsen dengan program penyuluhan khususnya atau pemberdayaan masyarakat pada umumnya. Hal ini masih jarang dilakukan oleh penyuluh yakni bekerja sama dengan lembaga lain semisal IMKOP, LSM, lembaga dakwah kampus IAIN Palopo, dan lembaga pemberdayaan masyarakat lainnya. ${ }^{27}$

\section{PENUTUP}

Model pembinaan keagamaan majelis taklim dalam peningkatan dakwah Kecamatan Wara Selatan antara lain berupa: a) kegiatan pengajian bulanan, b) pengajian takziyah, c) ceramah ramadhan, d) pembacaan yasinanshalawat e) pengajian pada acara aqiqah dan sebagainya. Bisa disimpulkan bahwa kegiatan dakwah pada majelis taklim ini berorientasi pada dakwah bil lisan dan dakwah bil hal melalui aktifitas bernuansa religius. Sedangkan tematema dakwah pada Majelis Taklim di Kecamatan Wara Selatan cukup bervariasi antara lain: a) tema dakwah tentang ibadah, surga dan neraka,

${ }^{26}$ Suhaemi dan Hj. Suarti, Pengurus Majelis Taklim Babul Khair Binturu dan Pengurus Majelis Taklim Citra Buana Takkalalla Kecamatan Wara Selatan, wawancara, pada tanggal 5 Nopember 2016.

${ }^{27}$ Ruhanda dan Fitri, Penyuluh Agama Islam di Kecamatan Kota Palopo, wawancara, pada tanggal 5 Nopember 2016. 
akidah dan tauhid, akhlak dan muamalah dan kisah-kisah para Nabi dan sahabat.

Hambatan yang dihadapi oleh mubalig yakni: a) secara struktural hampir semua program mubalig belum direncanakan dengan baik, b) sumber daya mubalig masih rendah dan kurang, c) lemahnya kemampuan metodologis para mubalig dalam memecahkan masalah masyartakat, d) kegiatan pelatihan dan workshop bagi mubalig masih kurang.

Adapun solusi yang dilakukan dalam mengatasi hambatan-hambatan yakni: a) memaksimalkan potensi kreatif mubalig dengan memberikan kesempatan untuk mengikuti seminar, pelatihan dan workshop penyuluhan, b) menghilangkan budaya menunggu pengarahan dari atas, c) mengefektifkan organisasi penyuluh agama Islam di lingkungan Kota Palopo, d) membuka peluang kerja sama dengan IAIN Palopo, IMKOP dan Pegawai Syara' guna menyentuh aspek pembinaan agama dan kehidupan sosial masyarakat Muslim.

\section{DAFTAR PUSTAKA}

Andrew Beatty, Adam and Eve and Vshnu: Syncretism in the Javanese Slametan" dalam Journal of the Royal Anthropological Institute 2, 1996. Lihat pula, Andrew Beatty, The Varieties of Javanese Religion, (Princeton University Press, 1999).

Clifford Geertz, The Religion of Java, (The United States of America: The University of Chicago Press, 1976), h. 5-7.

Dewan Redaksi Ensiklopedi Islam, Ensiklopedi Islam. (Cet. III; Jakarta: Ichtiar Van Hoeve, 1994), h. 120.

Didin Hafidhuddin, Dakwah Aktual, (Cet. I; Jakarta: Gema Insani, 1998), h. 88-96.

Niels Mulder, Agama, Hidup Sehari-hari dan Perubahan Budaya, (Jakarta: Gramedia Pustaka Utama, 1999).

Nur Syam, Islam Pesisir, (Cet. I; Yogyakarta: LKiS, 2005), h. vii. , (Jakarta: Gramedia Pustaka Utama, 1999).

Nurul Huda (e.d.), Pedoman Majelis Taílim (Jakarta: Koordinasi Dakwah Islam, 1987), h. 13.

Tim Penulis IAIN Syarif Hidayatullah, Ensiklopedi Islam (Jakarta: Djambatan, 1992), h. 207

Muhammad Fū'ad 'Abd al-Bāqi, al-Mu'jam al-Mufahras li Alfāz al-Qur'ān al-Karìm (Bairut: Dār al-Fikr, 1992), h. 330 